Volume 6, Nomor 2, 2020

ISSN (print) : 2442-3217

ISSN (online) : 2716-3806

Homepage : http://journal.iaimsinjai.ac.id/index.php/mimbar

\title{
TAREQAT KHALWATIYAH SAMMAN DI DESA TONGKE-TONGKE KEC. SINJAI TIMUR (Eksistensi dan Penyebaran Ajarannya)
}

\author{
Muh. Anis ${ }^{1 *}$, Desi Alawiyah ${ }^{2}$, Burhanuddin $^{3}$ \\ ${ }^{1}$ Institut Agama Islam Muhammadiyah Sinjai \\ Email: totangka077@gmail.com,Telepon: +6285299526057 \\ ${ }^{2}$ Institut Agama Islam Muhammadiyah Sinjai, Sinjai \\ Email: adhybugiez@gmail.com,Telepon:+628114178104 \\ ${ }^{3}$ Institut Agama Islam Muhammadiyah Sinjai \\ Email: rahmatullahiaim@gmail.com,Telepon: +6281268928954
}

\begin{abstract}
Abstrak
Penelitian ini membahas tentang ajaran tareqat Khalwatiyah, Perkembangan dan penyebaran ajaran tareqat khalwatiyah tanpak berjalan stagnan. Boleh jadi ini diakibatkan oleh gerakan organisasi dakwah lainnya organisasi dakwah ini dikenal dengan gerakan purifikasi ajaran Islam, sehingga terkesan kontra tasawuf-tareqat. Adapun fokus tema kajian mengenai eksistensi dan penyebaran ajaran tareqat Khalwatiyah. Penelitian ini bersifat kualitatif. Oleh karena itu, pembahasannya berupaya mendeskripsikan secara mendalam tentang fokus penelitian. Untuk membantu analisis digunakan pendekatan teori sejarah, teologi, dan sosiologi. Jenis dan pendekatan ini dipilih karena dipandang dapat membantu menggambarkan fenomena yang komprehensif. Dari hasil penelitian ini mengemukakan bahwa, Belum ditemukan keterangan valid mengenai kapan waktu pasti masuknya Tareqat Khalwatiyah khususnya Khalwatiyah Samman di Desa Tongke-Tongke. Akan tetapi berdasarkan telaah mendalam terhadap data-data yang terkumpul dan keterangan referensi yang ada, maka sejak akhir abad XIX ajaran Khalwatiyah Samman di Desa Tongke-Tongke telah dikenal. Berdasarkan data-data yang didapatkan, penyebaran ajaran tareqat Khalwatiyah Samman tidak hanya di wilayah kab. Sinjai saja. Akan tetapi di wilayah kabupaten tetangga seperti Bulukumba dan Bone banyak yang menjadi penganut tareqat Khalwatiyah Samman.

Kata Kunci : Ajaran tareqat, Khalwatiyah, gerakan organisasi dakwah, tasawuf-tareqat
\end{abstract}

\section{PENDAHULUAN}

Fenomena ilmu tasawuf dengan komunitas tareqat selalu menarik untuk dikaji. Tasawuf dan tareqat merupakan knowledge konsep mengenai eksistensi Allah Swt, proses mensucikan jiwa, zikir, dan ritual tertentu. Kedua istilah itu mendeskrepsikan ekspresi pemahaman keagamaan yang bersifat transenden, 
mistis, dan esensi. Pun, banyak kisah pengalaman spiritual bersifat supranatural yang melingkupinya.

Di dunia tasawuf dikenal konsep syariat, tareqat, hakikat, dan ma'rifat. Pemahaman mengenai konsep-konsep tersebut, secara teknis dan praktis diejawantahkan dalam komunitas tareqat. Pembelajaran syariat meliputi perintah, larangan, dan hukum Islam yang bersifat mendasar. Tareqat merupakan jalan atau metode memahami subtansi di balik syariat yang ada atau hakikat. Seseorang yang telah sampai pada tataran pemahaman mendalam tentang hakikat, maka ia telah sampai pada ma'rifat. Ma'rifat pengenalan sejati tentang eksistensi Allah Swt dan pemahaman hakiki tentang realitas di balik dunia nyata.

Di Indonesia keberadaan kelompok tareqat banyak tersebar di berbagai daerah. Ada beberapa tareqat yang mu'tabar dikenal, antara lain: Naqsyabandiyah, Qadiriyah, Sazdiliyah, Sattariyah, dan Khalwatiyah. Kelima tareqat itu cukup populer dan memiliki pengikut yang tidak sedikit diantara komunitas tareqat lain.

Eksistensi tasawuf-tareqat di Indonesia tidak jarang menimbulkan kontroversi. Ajaran dan ritual tertentu yang mereka amalkan menjadi penyebabnya. Bagi sebagian ulama ahli fiqh-fiqh ibadah, ritual yang dilakukan oleh kelompok tareqat dinilai bid'ah. Akan tetapi, sebagian ulama mendukungnya dengan alasan bahwa ritual itu merupakan metode dalam mendapat pencerahan batin. Meskipun ada pro dan kontra, komunitas tareqat di Indonesia tetap eksis. Bahkan, tidak jarang komunitas tareqat menjadi "lahan" perebutan pengaruh kepentingan politik tertentu.

Di Sinjai-Sulawesi Selatan, setidaknya ada dua komunitas tareqat yang aktif, yakni: Naqsyabandiyah dan Khalwatiyah. Tareqat Naqsyabandiyah berpusat di Kecamatan Sinjai Utara. Sedangkan tareqat Khalwatiyah berada di dua tempat yakni: di Desa Tongke-Tongke Kecamatan Sinjai Timur dan di Tafillasa-Desa Pattongko Kecamatan Sinjai Tengah.

Perkembangan dan penyebaran ajaran tareqat khalwatiyah tanpak berjalan stagnan. Boleh jadi ini diakibatkan oleh gerakan organisasi dakwah seperti Muhammadiyah, Wahdah Islamiyah, dan Salafiyah. Ketiga organisasi dakwah ini 
dikenal dengan gerakan purifikasi ajaran Islam, sehingga terkesan kontra tasawuftareqat. Di sisi lain, keberadaan pondok pesantren dengan sistem salafi,pun ditengarai turut mengekang ajaran penyebaran tasawuf-tareqat di Sinjai.

Berdasarkan uraian di atas, menarik untuk dikaji mengenai perkembangan dan penyebaran ajaran komunitas tareqat Khalwatiyah. Pemilihan fokus penelitian terhadap tareqat Khalwatiyah karena dari segi kuantitas, jumlah pengikutnya lebih tersebar luas dibanding dengan tareqat Naqsyabandiyah. Demikian pula kehadiran dan eksistensi komunitasnya di Sinjai, tareqat Khalwatiyah lebih awal hadir dibanding tareqat Naqsyabandiyah.

Beberapa hasil penelitian terkait dengan tareqat Khalwatiyah. Pembahasan dalam hasil penelitian ini dipandang memiliki korelasi dengan rencana penelitian ini. Oleh karena itu, deskripsi tentang hasil penelitian terdahulu dipandang penting untuk dipaparkan untuk menghindari plagiasi. Di bawah ini akan disinggung hasil penelitian dimaksud sebagai berikut:

Skripsi berjudul "Zikir (Maddate) dan Implementasinya (Tareqat Khalwatiyah Samman Dusun Cempa Desa Betao Riase Kecamatan Pitu Riawa Kabupaten Sidrap)" ditulis oleh Tamsir dan dikeluarkan oleh UIN Alauddin Makassar Fakultas Ushuluddin Filsafat dan Politik, tahun 2017. ${ }^{1}$ Skripsi berjudul “Kepatuhan Pengikut Ajaran Khalwatiyah Samman Terhadap Pemimpinnya Pada Pemilu Tahun 2014". Ditulis oleh Arfiandy dan dikeluarkan oleh Universitas Hasanuddin Makassar Fakultas Ilmu Sosial dan Ilmu Politik Jurusan Ilmu Politik Pemerintahan Program Studi Ilmu Politik, tahun 2015. ${ }^{2}$ Skripsi berjudul "Pola Komuniksi Antar pribadi Dikalangan Jamaah Terekat Sammaniyah Menurut Pandangan Al-Quran Di Desa Teluk Sentosa Kecamatan Panai Hulu Kabupaten

\footnotetext{
${ }^{1}$ Tamsir T., Skripsi, Zikir (Maddate) dan Implementasinya (Tareqat Khalwatiyah Samman Dusun Cempa Desa Betao Riase Kecamatan Pitu Riawa Kabupaten Sidrap), dikeluarkan oleh UIN Alauddin Makassar Fakultas Ushuluddin Filsafat dan Politik, 2017.

2 Arfiandy, Skripsi, Kepatuhan Pengikut Ajaran Khalwatiyah Samman Terhadap Pemimpinnya Pada Pemilu Tahun 2014, dikeluarkan oleh Universitas Hasanuddin Makassar Fakultas Ilmu Sosial dan Ilmu Politik Jurusan Ilmu Politik Pemerintahan Program Studi Ilmu Politik, 2015.
} 
Labuhan Batu”. Ditulis oleh Elfrida dan dikeluarkan oleh Fakultas Dakwah Dan Komunikasi Universitas Islam Negeri Sumatra Utara Medan, tahun 2017. ${ }^{3}$

Skripsi berjudul "Pesan Dakwah Dalam Ajaran Tarekat Khalwatiyah Samman (Analisis Hermeneutika Paul Ricoeur)'. Ditulis oleh A. Amrul Nurjaya dan dikeluarkan oleh UIN Alauddin Makassar Fakultas dakwah dan komunikasi Uin alauddin makassar, Tahun 2017. ${ }^{4}$ Skripsi berjudul "Strategi Adaptasi Tarekat Khalwatiyah Akmaliyah di Era Digital (Studi Kasus Di Desa Luwung Kecamatan Banyuputih Kabupaten Batang)". Ditulis oleh Lu'lu'atul Izzatir Rohmaniyah dan dikeluarkan oleh UIN Sunan Kalijaga Yogyakarta Fakultas Ushuluddin dan Pemikiran Islam, tahun $2018 .^{5}$

Merujuk hasil penelitian terdahulu sebagaimana dikutip, maka rencana penelitian ini ditemukan persamaan dan perbedaan. Persamaannya adalah samasama membahas keberadaan penganut tareqat Khalwatiyah. Perbedaannya adalah lokasi riset dan fokus tema pembahasan. Dalam riset ini lokasi penelitian berada terkhusus di Desa Tongke-Tongke Kecamatan Sinjai Timur. Adapun fokus tema kajian mengenai eksistensi dan penyebaran ajaran tareqat Khalwatiyah di tempat ini.

\section{LANDASAN TEORITIS}

\subsection{Konsep dan Korelasi Tareqat Dengan Tasawuf}

Kata tareqat diadopsi dari bahasa Arab yakni thariiqah, thariiq derivasi pluralnya yang semakna dengan kata shirath;jalan dan madzhab;Jalur yang ditempuh. Dalam kamus Bahasa Arab kata thariiqah yang diartikan sebagai cara,

${ }^{3}$ Elfrida, Skripsi, Pola Komuniksi Antar pribadi Dikalangan Jamaah Terekat Sammaniyah Menurut Pandangan Al-Quran Di Desa Teluk Sentosa Kecamatan Panai Hulu Kabupaten Labuhan Batu, dikeluarkan oleh Fakultas Dakwah Dan Komunikasi Universitas Islam Negeri Sumatra Utara Medan, 2017.

${ }^{4}$ A. Amrul Nurjaya, Skripsi, Pesan Dakwah Dalam Ajaran Tarekat Khalwatiyah Samman (Analisis Hermeneutika Paul Ricoeur), dikeluarkan oleh UIN Alauddin Makassar Fakultas dakwah dan komunikasi Uin alauddin makassar, 2017.

${ }^{5}$ Lu'lu'atul Izzatir Rohmaniyah, Skripsi, Strategi Adaptasi Tarekat Khalwatiyah Akmaliyah di Era Digital (Studi Kasus Di Desa Luwung Kecamatan Banyuputih Kabupaten Batang), dikeluarkan oleh UIN Sunan Kalijaga Yogyakarta Fakultas Ushuluddin dan Pemikiran Islam, 2018. 
metode atau sistem. ${ }^{6}$ Di dalam tradisi sufistik, tareqat dimaknai sebagai metode khusus untuk mencapai tujuan spiritual. ${ }^{7}$ Secara etimologi tareqat dapat dipahami sebagai jalan atau jalur. Tareqat merupakan metode atau sistem spiritual yang dipilih untuk tujuan tertentu.

Badriyah Syams mendefinisikan tareqat adalah suatu metode atau cara yang harus ditempuh seorang salik (orang yang meniti kehidupan sufistik). Metode itu ditempuh untuk tujuan pembersihan jiwa dalam rangka mendekatkan diri kepada Allah swt. ${ }^{8}$ Ada dua pemaknaan tareqat dalam perspektif ulama tasawuf, yakni: 1) Jalan kepada Allah dengan mengamalkan ilmu Tauhid, Fiqih dan Tasawuf. 2) Cara atau kaifiat mengerjakan sesuatu amalan untuk mencapai suatu tujuan. ${ }^{9}$ Tareqat dipahami sebagai petunjuk beribadah sebagaimana dicontohkan oleh Nabi Muhammad saw. Dan, seterusnya secara geneologis diamalkan sahabat-sahabat Nabi saw, tabi'in dan tabi'-tabiin. Kemudian berlanjut kepada guru-ulama hingga masa sekarang. ${ }^{10}$

Rosihan Anwar mengutip pendapat John O Voll bahwa awal kemunculan tareqat sebagai metode spiritual diperkenalkan oleh tiga tokoh, yakni: Syekh Abdul Qadir Al-Jailani-tareqat Qadiriyah di Baghdad, Sayyid Ahmad Ar-Rifa'itareqat Rifa'iyah di Mesir, dan Jalal Al-Din Al-Rumi-tareqat Maulawiyah di Persia. ${ }^{11}$ Dalam kata lain, ketiga tokoh inilah yang pertama kali mengajarkan metode spiritual sebagai sistem. Suatu sistem spiritual pembersihan jiwa yang bertujuan mendekatkan diri kepada Allah swt. Sistem yang berlandaskan pemahaman mendalam terhadap ilmu tauhid, fiqih, dan tasawuf. Pengamalan

\footnotetext{
${ }^{6}$ Abd. Bin Nuh dan Oemar Bakry, Kamus Arab-Indonesia-Inggris, Cet. 15; Jakarta: Mutiara Sumber Widya, 2004, h. 170.

${ }^{7}$ Ajid Thohir, Gerakan Politik Kaum Tareqat: Telaah Historis Gerakan Politik Antikolonialisme Tareqat Qodiriyah-Naqsabandiyah di Pulau Jawa, Cet.I; Bandung: Pustaka Hidayah, 2002, h. 47.

${ }^{8}$ Badriyah Syams, Tareqat sebagai Cara Pendekatan Diri Kepada Allah, Cet. I; Tangerang : CV. Sejahtera Kita, 2010, h. 1.

${ }^{9}$ A. Fuad Said, Hakikat Tarikat Naqsyabandiyah, Hakikat Tarikat Naqsyabandiyah. Jakarta: Pustaka Al Husna Baru, 2005, h. 6.

${ }^{10}$ Mustafa Zahri, kunci memahami ilmu tasawuf, Cet. I; Surabaya: Bina Ilmu Offset, 1995, h. 56 . h. 208 .
} 
sistem spiritual ini, diyakini bersifat hirarkis-geneologis mencontoh Nabi saw hingga generasi masa kini.

Pada beberapa literatur, didapatkan beberapa unsur-unsur eksistensi suatu tareqat,yaitu: Pertama, Mursyid. Mursyid adalah pembimbing yang diyakini telah mukasyafah; telah terbuka tabir antara dirinya dan Tuhan. Mursyid merupakan fasilitator menemani dan membimbing para salik;penempuh jalan spiritual untuk mendekati Allah. Guru spiritual itu kadang disebut dengan istilah thayr al-quds (burung suci) atau Khidir. Dalam tareqat, bimbingan guru yang telah mengalami perjalanan rohani secara pribadi dan mengetahui prosedurprosedur setiap mikraj rohani adalah sangat penting. ${ }^{12}$ Kedua, Baiat. Baiat-talqin ;janji setia seorang murid kepada guru. Salik akan mengikuti apa pun yang diperintahkan oleh guru, tanpa "reserve". ${ }^{13}$ Ketiga, Silsilah. Silsilah adalah nisbah;penegasan ketersambungan-keterakaitan guru-guru terdahulu sampai kepada Nabi saw. Silsilah harus ada sebab bimbingan keruhanian yang diambil dari guru-guru itu harus benar-benar berasal dari Nabi saw. Kalau tidak demikian halnya berarti tareqat itu terputus dan palsu, bukan warisan dari Nabi saw. ${ }^{14}$ Keempat, salik;Murid. Salik adalah orang yang sedang mendapat bimbingan pencarian dan perjalanan spiritual mendekati Allah swt. Tanpa bimbingan guru yang berpengalaman melewati berbagai tahap (maqamat) dan mampu mengatasi keadaan jiwa (hal), salik mudah tersesat dan gagal. ${ }^{15}$ Kelima, Ajaran. Ajaran adalah praktik-praktik dan ilmu-ilmu tertentu yang diajarkan dalam sebuah tareqat. Setiap tareqat memiliki kekhasan ajaran dan metode khusus dalam mendekati Tuhan. ${ }^{16}$

Membaca dan memahami unsur-unsur eksistensi suatu tareqat, maka ada kesimpulan yang menjadi catatan. Pertama, kunci utama benar salah perjalanan spiritual salik ada dalam petunjuk Mursyid sebagai fasilitator. Mursyid tidak

12 Ahmad Najib Burhani, Tareqat tanpa Tareqat,Cet.I; Jakarta: Serambi Ilmu Semesta, 2002, h. 36.

${ }^{13}$ Ahmad Najib Burhani, Tareqat tanpa...., h.37

${ }^{14}$ Sri Mulyati, Mengenal dan Memahami Tareqat-Tareqat Muktabarah di Indonesia, Cet IV; Jakarta: Prenada Media Group, 2011, h. 9-10.

${ }^{15}$ Ahmad Najib Burhani, Tareqat tanpa Tareqat, Cet.I; Jakarta: Serambi Ilmu Semesta, 2002, h. 37.

${ }^{16}$ Ahmad Najib Burhani, Tareqat Tanpa..., h. 38. 
hanya sebagai fasilitaor, tetapi dia juga bertindak sebagai transfomator. Kedua, baiat atau sumpah setia tanpa penolakan mengikuti arahan Mursyid merupakan dogma-doktrin bersifat otoritatif. Ketiga, baiat yang otoritatif merupakan bentuk radikalisme dogma-doktrin yang diperkuat oleh validasi silsilah. Sejatinya, salik yang memilih suatu tareqat merupakan fatalis bukan tanpa alasan kuat.

Tarekat ditempuh oleh para sufi atau Zahid di sepanjang zaman. Setiap zahid mungkin mempunyai pengalaman yang berbeda-beda menuju kepada Tuhan. Perbedaan pengalaman spiritual ini, disebut sebagai ittihad;kesatuan dengan Ilahi secara mistik dan dalam arti majasi/nisbi ataupun hakiki. Para ahli tasawuf sepakat untuk memilih tahapan-tahapan perjalanan spiritual yang diistilahkan maqamat; etape dan ahwal;keadaan. Maqamat dicapai melalui usaha sadar dan sistematis, sedangkan ahwal adalah keadaan jiwa secara spontan sebagai karamah; anugerah dari Ilahi, umumnya terjadi relatif cepat. ${ }^{17}$ Ketika salik mencapai maqamat tertentu, maka itu adalah pengalaman unik. Demikian pula, ketika salik mengalami ahwal maka itu merupakan pengalaman spiritual yang langka. Keadaan supranatural itu terjadi saat kasyaf;ekstase karena "merasa" ittihad; menyatu dengan Tuhan.

Setelah meneliti kehidupan tasawuf dibeberapa negara Islam, Ahmad Mustofa menarik kesimpulan bahwa tareqat mempunyai dua pengertian, yakni: 1) Tareqat yang diartikan sebagai pendidikan kerohanian. Dilakukan oleh orangorang yang menempuh kehidupan tasawuf. Tujuannya untuk mencapai tingkatan kerohanian yang disebut "Al-Maqamat" dan "Al-Ahwal". Pengertian seperti ini, menonjol sekitar abad ke-IX dan ke-X Masehi. 2) Tareqat diartikan sebagai perkumpulan yang didirikan menurut aturan yang telah dibuat oleh seorang Syekh yang menganut aliran tareqat tertentu. Dalam perkumpulan itu, seorang Syekh mengajarkan Ilmu Tasawuf menurut aliran tareqat yang dianut dan diamalkan bersama dengan murid-muridnya. Pengertian seperti ini, menonjol sesudah abad ke-IX Masehi. ${ }^{18}$

\footnotetext{
${ }^{17}$ Moenir Nahrowi Tohir, Menjelajahi Eksistensi Tasawuf; Meniti Jalan Menuju Tuhan, Cet.I; Jakarta: As Salam Sejahtera, 2012, h. 87-88.

${ }^{18}$ Ahmad Mustafa, Akhlak Tasawuf, Cet. I; Bandung: CV. Pustaka Setia, 2010, h. 281.
} 
Tarekat merupakan aliran dari tasawuf (mistik islam), akan tetapi bukan mistik/klenik. Tasawuf menurut Ibn Khaldun berarti ilmu syariah yang timbul dalam Islam. Berawal dari tekun beribadah dan memutuskan perhatian dengan segala selain Allah, hanya mengharap Allah semata, menolak hiasan dunia, serta membenci perkara yang selalu memperdaya orang atas kelezatan harta benda dan kemegahan dunia, menyendiri menuju jalan Allah dalam khalwat dan ibadah. ${ }^{19}$ Tasawuf merupakan salah satu cabang ilmu Islam yang lebih menekankan kepada dimensi batin atau spiritual. Secara umum pengertian tasawuf adalah kecenderungan mistisme universal yang ada sejak dahulu kala, berasaskan sikap zuhud terhadap keduniaan (asketisme), dan bertujuan membangun hubungan (ittishal) dengan al-mala' al-a 'la yang merupakan sumber kebaikan, emanasi, dan ilumunasi. $^{20}$

Ada bermacam-macam pendapat tentang makna kata tasawuf, akan tetapi secara substansial tasawuf berarti usaha mendekatkan diri kepada Tuhan dengan cara mensucikan rohani dan memperbanyak ibadah. Sehingga manusia pun mulai melakukan pencarian dengan menempuh perjalanan rohani menuju Tuhannya, inilah yang disebut tariqat. Manusia harus berjuang dalam takhalli;mensucikan jiwanya dari kotoran-kotoran dan pengaruh-pengauh jasmani. Dia harus tahalli ;mengisi dirinya dengan sifat yang baik. Terakhir, dia harus tajalli; mengamalkan dan menerapkanya dalam kehidupan sehari-hari. ${ }^{21}$ Seseorang yang bertasawuf harus memenuhi syarat-syaratnya. Dalam kata lain, sangat penting bagi salik memahami dan mengamalkan Takhali, Tahalli, dan Tajalli.

Terkait dengan pemahaman istilah Takhali, Tahalli, dan Tajalli, Nurcholis Madjid, mengatakan bahwa seseorang yang mengamalkannya berarti menempuh jalan yang benar secara mantap dan konsisten. Orang yang demikian dijanjikan Tuhan akan memperoleh karunia hidup bahagia yang tiada terkira. Hidup bahagia itu ialah hidup sejati, yang dalam ayat suci diumpamakan dengan air yang

\footnotetext{
${ }^{19}$ Sri Mulyati, Mengenal dan Memahami...., h. 8.

${ }^{20}$ Muhammad Fauqi Hajjaj, Tasawuf Islam dan Akhlak, terj. Kamran As'at Irsyady dan Fakhri Ghazali, Cet. I; Jakarta: Amzah, 2011, h. 3.

${ }^{21}$ Mustafa Zahri, Kunci Memahami Ilmu Tasawuf, Cet. I; Surabaya: Bina Ilmu Offset, 1995, h. 45.
} 
melimpah ruah. Dalam literatur kesufian, air karunia illahi itu disebut "air kehidupan". Inilah yang secara simbolik dicari oleh para pengamal tarekat, yang wujud sebenarnya tidak lain ialah "pertemuan" dengan tuhan dengan ridla-Nya. ${ }^{22}$

Pendapat Nurkholis Majid searah dengan pernyataan J.S. Trimingham dalam Ajid Thohir, yang mengatakan bahwa tareqat adalah:

A practical method (other terms were madhhab, ri'ayah and suluk) to guide a seeker by tracing a way of thought, feeling and action, leading a succession of stages (maqamat, an integral association with psycological experience called 'states,' ahwal) to experience of Divine Reality (haqiqa). ${ }^{23}$

\subsection{Eksistensi Tareqat Khalwatiyah}

Pada abad pertama hijriyah mulai ada wacana diskusi tentang teologi Islam. Diskusi teologi ini melahirkan ilmu tasawuf pada abad kedua Hijriyah. Tasawuf terus berkembang dan meluas sebagai cabang ilmu keislaman, akan tetapi mulai terpengaruh filsafat, seperti: filsafat Yunani, India, dan Persia. Kemudian praktisi ilmu tasawuf di sebut sufi. Tujuan utama amalan ajaran Islam para sufi untuk kesucian jiwa untuk taqarrub kepada Allah. Para sufi kemudian membedakan pengertian syari'ah, thariqat, haqiqat, dan makrifat. Syari'ah itu untuk memperbaiki amalan-amalan lahir, thariqat untuk memperbaiki amalanamalan batin (hati), haqiqat untuk mengamalkan segala rahasia yang ghaib, sedangkan makrifat adalah tujuan akhir yaitu mengenal hakikat Allah baik zat, sifat maupun perbuatanNya. ${ }^{24}$

Abad pertama hijriyah Islam tidak lagi berkutat di jazirah Arab. Islam telah telah dikenal dan dianut oleh non Arab, yang terlebih dahulu telah berkembang tradisi berpikirnya. Ketika ajaran Islam berhadapan dengan paradigma masyarakat tersebut melahirkan diskursus terutama konsep tentang Tuhan. Akumulasi diskusi wacana transenden mendalam dua konsep antara Islam dan budaya pikir setempat, kemudian melahirkan ilmu baru yakni tasawuf. Sufi menjadi nama khas praktisi tasawuf karena karakter, identitas, dan ekspresi pengamalan ajaran Islam versi mereka. Konsentrasi praktek keagamaan untuk

\footnotetext{
${ }^{22}$ Nurcholis Madjid, Islam Agama Peradaban, Cet. I; Jakarta: Paramadina, 1995, h.109.

${ }^{23}$ Nurcholis Madjid, Islam Agama....., h. 48.

${ }^{24}$ Sri Mulyati, Mengenal dan Memahami ....., h. 6.
} 
tujuan pensucian jiwa agar mampu "bertemu" dengan Tuhan, melahirkan tahaptahap filosofis dalam istilah syariat, tareqat, haqikat, dan ma'rifat.

Pada abad ke-3 hingga ke-4 Hijriyah menjadi awal kemunculan tareqat yang sejalan dengan ilmu tasawuf. Pada abad ke-5 Hijriyah muncul tareqat sebagai komunitas dalam bentuk kegiatan kaum sufi. Mula-mula muncul tareqat Qodiriyah yang dikembangkan oleh syeikh Abdul Qodir Jaelani di Asia tengah Tibristan tempat kelahiran dan oprasionalnya, kemudian berkembang ke Baghdad, Irak, Turki, Arab Saudi sampai ke Indonesia, Singapura, Malaysia, Thailand, India, Tiongkok. Muncul pula tareqat Rifa'iyah di Maroko dan Aljazair. Disusul tareqat Suhrawardiyah di Afrika utara, Afrika tengah, Sudan dan Nigeria. Tareqattareqat itu kemudian berkembang dengan cepat melalui murid-murid yang diangkat menjadi khalifah, mengajarkan dan menyebarkan ke negeri-negeri Islam, bercabang dan beranting hingga banyak sekali. ${ }^{25}$

Abad ke-3 hingga Abad ke-5 tanpak ilmu tasawuf terkonsentrasi dan terkonsolidasi dalam bentuk kelompok tareqat. Pengamalan ilmu tasawuf secara tareqat pada abad ke-5 mencapai puncak perkembangan dan penyebarannya. Tasawuf-tareqat telah menjadi mainstream pada abad ke-5 dan menarik perhatian banyak orang. Penyebaran dan pengaruhnya di wilayah yang luas dan berbagai bangsa, menunjukkan tasawuf-tareqat memiliki daya tarik tersendiri. Ilmu tasawuf dan pengamalan tareqat menjadi opsi bagi sebagaian orang untuk mendapatkan kepuasan dalam beragama.

Umumnya sejarahwan berpendapat bahwa penyebaran agama Islam di Nusantara, melalui lima cara pendekatan, yakni: perdagangan, pendidikan, perkawinan, politik, dan tasawufltareqat. Pendekatan tasawuf dinilai signifikan banyak berperanan dalam islamisasi. Karakteristik penggiat tasawuf yang sederhana, egaliter, dan menyentuh langsung grassroot, meyebabkan Islam mudah tersebar luas. Selain itu, ajaran tasawuf tidak terlalu peduli dengan strata sosial yang ada. Dalam kata lain, setiap orang mempunyai peluang untuk mencapai maqam spiritual tinggi tanpa dipengaruhi latar belakang status sosial.

${ }^{25}$ Sri Mulyati, Mengenal dan Memahami .... h. 7. 
Mengapa pendekatan tasawuf-tareqat menyebabkan Islam tersebar massif di tengah masyarakat? Zamakhsyari dhofier mengemukakan alasan, bahwa: pertama, tekanan tareqat pada amalan-amalan yang bersifat praktis cukup menarik perhatian kebanyakan anggota masyarakat. kedua, pertemuan yang dilakukan secara teratur antara sesama anggota tareqat dapat memenuhi kebutuhan sosial diantara pengikut tareqat tersebut. ketiga, organisasi-organisasi tareqat yang ada di pulau Jawa mengajak partisipasi kaum perempuan secara penuh yang biasanya kurang terwadahi secara maksimal dalam lembaga-lembaga keislaman lainnya. ${ }^{26}$

Alwi Shihab mengatakan di antara tareqat-tareqat yang memperoleh simpati dan banyak pendukungnya di Indonesia adalah tareqat Khalwatiyah, Syatariyah, Qadiriyah, dan 'Alawiyah. Khalwatiyah kebanyakan pengikutnya berasal dari Sulawesi Selatan, tareqat Syatariyah kebanyakan muridnya dari Sumatera Selatan, kamudian tareqat Qadiriyah banyak tersebar di berbagai wilayah Indonesia, sementara itu tareqat 'Alawiyah tersebar di Indonesia melalui keturunan 'Alawiyyin dan murid-muridnya. Petunjuk tentang penyebaran dan diterimanya tareqat-tareqat ini oleh masyarakat Indonesia, karena kebanyakan ulama yang kembali dari Hijaz menganut tareqat tersebut dan berpegang teguh kepada Al-Qur'an dan Sunnah. Oleh sebab itu, bentuk tareqat di Indonesia, seperti halnya di negeri muslim, tidak lain merupakan kesinambungan dari tasawuf suni Al-Ghazali. ${ }^{27}$

Pada perkembangannya, muncul kelompok tareqat dengan segala perbedaan dan karakteristik masing-masing. Di Indonesia dikenal dua istilah tareqat, yakni: tareqat mu'tabar; terpercaya dan tareqat gairu mu'tabar; tidak terpercaya. Aboebakar Atjeh merilis 41 kelompok tareqat mu'tabar, antara lain:

1. Qadiriyyah, 2. Naksyabandiyah, 3. Syaziliyah, 4. Rifa'iyyah, 5. Ahmadiyyah, 6. Dasukiyyyah, 7. Akbariyah, 8. Maulawiyyah, 9. Qurabiyyah, 10. Suhrawardiyyah, 11. Khalwatiyyah, 12. Jalutiyyah, 13. Bakdasiyah, 14. Ghazaliyah, 15. Rumiyyah, 16. Jatsiyyah, 17. Sya'baniyyah, 18. Shiddiqiyyah, 19. Qusyasyiyyah, 20. Tijaniyyah, 21. 'Alawiyyah, 22. 'Usyaqiyyah, 23. Bakriyyah, 24.'Umariyyah, 25.

${ }^{26}$ Zamakhsyari Dhofier, Tradisi Pesantren : Studi Pandangan Hidup yai dan Visinya Mengenai Masa Depan Indonesia, Cet. XI; Jakarta : LP3ES, 2011, h. 223-224.

${ }^{27}$ Alwi Shihab, Akar Tasawuf di Indonesia, Cet. I; Depok; Pustaka IIMaN, 2009, h. 186. 
'Usmaniyyah, 26. 'Aliyyah, 27. Abbasiyah, 28. Haddadiyyah, 29. Maghribiyyah, 30. Ghaibiyyah, 31. Hadiriyyah, 32. Syattariyyah, 33. Bayumiyyah, 34. Aidrusiyyah, 35. Sanbliyyah, 36. Malawiyyah, 37. Anfasiyyah, 38. Sammaniyyah, 39. Sanusiyyah, 40. Idrisiyah 41. Badawiyyah. ${ }^{28}$

Memperhatikan rilis Aboebakar Atjeh tersebut, tidak satupun ada nama tareqat Khalwatiyah. Padahal tareqat khalwatiah di Indonesia bukan suatu yang asing. Tareqat ini cukup populer di Sulawesi Selatan karena relatif banyak pengikut. Menyebut nama Syekh Yusuf Al Makassary di Sulawesi Selatan, maka orang akan mengingat tokoh tareqat Khalwatiyah. Bahkan, Syekh diberi gelar Tajul al Khawaty;Mahkota Khalwatiyah. Di tempat kelahiran dikenal dengan nama Tuanta Salamaka ri Gowa; Tuan Guru Penyelamat Kita dari Gowa. Meskipun wafat di Capetown-Afrika Selatan, akan tetapi ada makam di KatangkaGowa dipercaya sebagai makamnya.

Tareqat Khalwatiyah adalah salah satu cabang dari tareqat Syuhrawadiyah yang didirikan di Baghdad oleh Abdul Kadir Syuhrawardi (w.1167/562H) dan Umar Suhrawardi (w.1234/623 H). Tareqat Syuhrawardiyah dinamakan tareka Shiddiqiah (dihubungkan kepada Abu Bakar Shidiq sebagai akhir dari mata rantai sanadnya) banyak berkembang di Afganistan dan India, dan mempunyai banyak cabang diantaranya Jamaliayah, Jalalliyah, Zainiyah, Safawiyah, Rausaniyah dan Khalwatiyah. Secara "nasabiyah”, Tareqat Khalwatiyah merupakan cabang dari Tareqat Az-Zahidiyah, cabang dari Al-Abhariyah, dan cabang dari AsSuhrawardiyah, yang didirikan oleh Syekh Syihabuddin Abi Hafs Umar asSuhrawardi al-Baghdadi (539-632 H). ${ }^{29}$

Syekh Muhammad Al-Khalwati adalah pendiri Tarekat Khalwatiyah. Nama Khalwatiyah diambil dari kata khalwat;menyendiri untuk merenung. Penyematan nama ini diberikan ajaran Syekh Muhammad, karena ia gemar melakukan khalwat di tempat-tempat sepi. Tareqat Khalwatiyah dibawa ke Mesir oleh Musthafa bin Kamaluddin bin Ali al-Bakri as-Shiddiqi, seorang penyair sufi asal Damaskus-Syria. Ia mengambil tarekat tersebut dari gurunya yang bernama

\footnotetext{
${ }^{28}$ Aboebakar Atjeh, Pengantar Ilmu Tareqat (Uraian Tentang Mistik), Cet.I; Solo: Ramadhani, 1985, h. 303-304.

${ }^{29}$ Syakirin Al-Ghozaly, Ilmu Tasawuf Sebuah Pengantar, Cet. I; Sukoharjo: AIS- Aswaja Institut Surakarta, 2010, h. 74.
} 
Syekh Abdul Latif bin Syekh Husamuddin al-Halabi. Oleh karena tareqat ini berkembang pesat di Mesir, maka Musthafa al-Bakri dianggap tokoh penting oleh para pengikut Khalwatiyah. ${ }^{30}$ Menelusuri asal usul tareqat Khalwatiyah tanpak rumit. Kemunculannya ditengarai sebagai pecahan dari tareqat Syuhrawardiyah.

Ada 10 ajaran mendasar dalam tareqat khalwatiyah, yakni: Pertama, Yaqza; kesadaran akan dirinya sebagai makhluk yang hina di hadapan Allah Swt Yang Maha Agung. Kedua, Taubah; mohon ampun atas segala dosa. Ketiga, Muhasabah; menghitung-hitung atau introspeksi diri. Keempat, Inabah; berhasrat kembali kepada Allah. Kelima, Tafakkur; merenung tentang kebesaran Allah. Keenam, I'tisam; selalu bertindak sebagai Khalifah Allah di bumi. Ketujuh, Firar; lari dari kehidupan jahat dan keduniawian yang tidak berguna. Kedelapan, Riyadah; melatih diri dengan beramal sebanyak-banyaknya. Kesembilan, Tasyakur; selalu bersyukur kepada Allah dengan mengabdi dan memujinya. Kesepuluh, Sima'; mengkonsentrasikan seluruh anggota tubuh dan mengikuti perintah-perintah Allah terutama pendengaran. ${ }^{31}$

Kesepuluh rumusan dogma-doktrin tersebut menunjukkan Khalwatiyah sebagai tareqat. Dan, sepuluh ajaran dasar ini pula, menunjukkan dogma tareqat Khalwatiyah pada tataran syariat. Rumusan ini bersifat doktrin yang oleh setiap pengikut, tidak hanya dipelajari, dipahami, tetapi juga wajib diamalkan. Pengamalan sepuluh rumusan itu dapat dikatakan pondasi untuk menyiapkan diri memperoleh pengalaman spiritual.

Pada proses kontenplasi, tareqat Khalwatiyah mengajarkan kepada salik Al-Asma' As-Sab'ah;tujuh nama dalam ritual zikir;mengingat Allah. Ketujuh macam zikir itu adalah,

a. Dzikir pertama adalah La ilaaha illallah (pengakuan bahwa tiada Tuhan selain Allah).

b. Kedua, Allah (Allah). Pada tingkatan jiwa kedua ini disebut an-Nafs alLawwamah (jiwa yang menegur).

c. Ketiga, Huwa (Dia). Dzikir pada tingkatan ketiga ini disebut an-Nafs alMulhamah (jiwa yang terilhami).

\footnotetext{
${ }^{30}$ Wikipedia, 2018 https://id.wikipedia.org/wiki/Tarekat_Khalwatiyah, di akses tgl 21 Nopember 2019.

${ }^{31}$ Abu Hamid, Syeikh Yusuf Tajul Khalwat; Suatu Kajian Antropologi Agama, Cet. I; Ujung Pandang, Disertasi Ph.D Universitas Hasanuddin, 1990, h. 181.
} 
d. Keempat, Haq (Maha Benar). Tingkatan jiwa ini disebut an-Nafs alMuthmainnah (jiwa yang tenang).

e. Kelima, Hay (Maha Hidup). Disebut juga dzikir an-Nafs ar-Radliyah (jiwa yang ridla).

f. Keenam, Qayyum (Maha Jaga). Tingkatan jiwa ini disebut juga an-Nafs Mardliyah (jiwa yang diridlai).

g. Ketujuh, Qahhar (Maha Perkasa). Jiwa ini disebut juga an-Nafs alKamilah (jiwa yang sempurna). ${ }^{32}$

Konsep Al-Asma' As-Sab'ah dalam tareqat Khalwatiyah menunjukkan suatu metode khas. Suatu metode kontenplasi yang diyakini dapat memediasi seorang salik lebih dekat dengan Ilah. Pengalaman spiritual yang didapatkan oleh salik ketika mengamalkan metode ritual kontenplasi tareqat yang diikuti, pada dasarnya bersifat privasi. Fenomena yang disaksikan merupakan ahwal yang tidak dapat dideskripsikan kepada orang lain. Satu-satunya orang yang mampu menerangkan "pengalaman rasa" itu adalah mursyid.

\section{METODE PENELITIAN}

\subsection{Jenis dan Pendekatan}

Penelitian ini bersifat kualitatif. Oleh karena itu, pembahasannya berupaya mendeskripsikan secara mendalam tentang fokus penelitian. Untuk membantu analisis digunakan pendekatan teori sejarah, teologi, dan sosiologi. Jenis dan pendekatan ini dipilih karena dipandang dapat membantu menggambarkan fenomena yang komprehensif. Dalam penelitian kualitatif, peneliti merupakan instrumen utama. Karena itu, peneliti dituntut untuk memberikan gambaran fenomena sebagaimana adanya.

\subsection{Lokasi, Subjek dan Objek Penelitian}

Lokasi Penelitian adalah tempat yang berkaitan dengan sasaran atau permasalahan penelitian dan juga merupakan salah satu jenis sumber data yang dapat dimanfaatkan oleh peneliti. ${ }^{33}$ Pemilihan lokasi atau site selection ditetapkan berkenaan dengan penentuan unit, bagian, kelompok, dan tempat dimana orangorang terlibat di dalam kegiatan atau peristiwa yang akan diteliti. ${ }^{34}$ Lokasi

\footnotetext{
${ }^{32}$ Syakirin Al-Ghozaly, Ilmu Tasawuf ..... h. 75.

${ }^{33}$ Sutopo, Metodologi Penelitian Kualitatif, Cet. I; Surakarta: Sebelas Maret University Press, 2002, h. 52.

${ }^{34}$ Sukmadinata, Metode Penelitian Pendidikan,Cet. I; Bandung:Rosdakarya,2007, h. 102.
} 
penelitian ini, di Desa Tongke-Tongke Kecamatan Sinjai Timur. Subjek penelitian adalah elit dan penganut tareqat Khalwatiyah, sedangkan objeknya histori eksistensi, perkembangan, dan penyebaran ajaran tareqat Khalwatiyah.

\subsection{Sumber Data}

Pada penelitian kualitatif menekankan pada makna dan lebih memfokuskan pada data kualitas dengan analisis kualitatifnya dan tetap memandang data kuantitas sebagai fenomena untuk mendukung analisis kualitatif bagi pemantapan makna sebagai simpulan akhir penelitian. Sumber data terdiri dari narasumber (informan), peristiwa atau aktivitas, tempat atau lokasi, benda, gambar, dan rekaman, serta dokumen ${ }^{35}$

Pada penelitian ini ada dua kategorisasi sumber data, yakni Sumber Data Primer dan Sumber Data Sekunder. Sumber Data Primer adalah hasil observasi dan hasil wawancara dengan nara sumber yang kompoten. Narasumber di sini adalah praktisi ajaran tareqat Khalwatiyah yakni pimpinan dan pengikutnya. Sedangkan Sumber Data Sekunder didapatkan dari hasil bacaan dari berbagai Karya Tulis Ilmiah, seperti: Artikel, Skripsi, dan Tesis yang korelasi dengan tareqat Khalwatiyah.

\subsection{Teknik Pengumpulan Data}

Secara teknis pengumpulan data dalam penelitian ini, menempuh langkahlangkah sebagai berikut: 1) Mengumpulkan literatur referensi tertulis yang terkait erat dengan fokus penelitian ini. Dalam hal ini dilakukan riset pustaka atau library research. 2) Melakukan observasi. Dalam hal peneliti akan mengunjungi tempat yang menjadi lokasi penelitian. Kunjungan ini dilakukan dalam rangka mengamati prilaku dan aktifitas pelaksanaan ajaran tareqat Khalwatiyah. 3) Melakukan Wawancara. Untuk mempermudah pelaksanaan wawancara, maka dibuat terlebih dahulu konsep atau pedoman wawancara. Hal ini dilakukan agar dialog berjalan sistematis dan data atau keterangan yang diinginkan didapatkan. 4) Dokumentasi. Dokumentasi juga ditempuh dalam penelitian ini sebagai alat untuk membuktikan

\footnotetext{
${ }^{35}$ Sutopo, Metodologi Penelitian...., h. 48, 50, 54.
} 
fakta kejadian di lapangan. ${ }^{36}$ Selain itu, dapat menjadi bukti pertanggungjawaban pelaksanaan riset ini.

\subsection{Teknik Analisis Data}

Teknik analisis data adalah proses pengumpulan data secara sistematis untuk mempermudah peneliti dalam memperoleh kesimpulan. Analisis data yaitu proses mencari dan menyusun secara sistematik data yang diperoleh dari hasil wawancara, catatan lapangan, dan bahan-bahan lain sehingga dapat mudah dipahami dan temuannya dapat diinformasikan kepada orang lain. ${ }^{37}$ Oleh karena itu, ditempuh tiga alur kegiatan yang terjadi secara bersamaan yaitu: Reduksi Data, diartikan sebagai proses pemilihan, pemusatan perhatian pada penyederhanaan, pengabstrakan, dan transformasi data kasar yang muncul dari catatan-catatan tertulis di lapangan. Reduksi data berlangsung terus-menerus selama proyek yang berorientasi penelitian kualitatif berlangsung. Penyajian Data, suatu penyajiansebagai sekumpulan informasi tersusun yang memberi kemungkinan adanya penarikan kesimpulan dan pengambilan tindakan. Mereka meyakini bahwa penyajian-penyajian yang lebih baik merupakan suatu cara yang utama bagi analisis kualitatif yang valid. Penarikan Kesimpulan/verifikasi, merupakan satu kegiatan dari konfigurasi yang utuh. Diawali dengan verikasi secara berkesinambungan, yakni: makna-makna yang muncul dari data yang lain harus diuji kebenarannya, kekokohannya, dan kecocokannya, yakni yang merupakan validitasnya. Kesimpulan akhir tidak hanya terjadi padawaktu proses pengumpulan data saja, akan tetapi perlu diverifikasi agar benar-benar dapat dipertanggungjawabkan. ${ }^{38}$

\subsection{Validasi Data}

Penelitian ini menggunakan teknik validitas data dengan triangulasi. Triangulasi adalah teknik pemeriksaan keabsahan data yang memanfaatkan sesuatu yang lain di luar data untuk keperluan pengecekan atau sebagai

\footnotetext{
${ }^{36}$ Sutopo, Metodologi Penelitian...., h. 58-69.

${ }^{37}$ Sugiyono, Memahami Penelitian Kualitatif,Cet. I; Bandung: Alfabeta, 2009, h. 334.

${ }^{38}$ Milles dan Huberman, Analisis Data Kualitatif, Cet. I; Jakarta: Universitas Indonesia Press, 1992, h. 16.
} 
pembanding terhadap hal tersebut. ${ }^{39}$ Secara teknis, data-data Primer dan Sekunder dikaji secara komprehensif dan simultan. Apabila didapatkan data yang kontradiski maka akan dikonfrontasikan, sehingga didapatkan kesimpulan yang meyakinkan. Dengan demikian argumentasi terhadap pemilihan suatu pernyataan dapat dipertanggungjawabkan. Selain itu, triangulasi ditempuh agar generalisasi dapat disusun apabila dibutuhkan.

\section{PEMBAHASAN}

\subsection{Selayang Pandang Desa Tongke-Tongke Sinjai Timur ${ }^{40}$}

Berdirinya Desa Tongke-Tongke berpijak pada Undang-Undang Nomor 22 tahun 1999 tentang Otonomi Daerah dan Peraturan Pemerintah tentang Pemerintahan Desa. Dusun-dusun dalam wilayah Desa Tongke-Tongke, seperti: Babana, Bentengnge, Baccara, Cempae, dan Maroanging, masih berada dalam wilayah Kelurahan Samataring Kecamatan Sinjai Timur Kab. Sinjai. Tahun 2002 diberikan amanah kepada $H$. Alimuddin untuk persiapan menjadi wilayah pemerintahan desa. Pada tanggal 8-11 Februari 2003 diselenggarakan pemilihan Calon Kepala Desa. Pemilihan ini akhirnya menetapkan Muh. Nasri Daeng Lanna sebagai Kepala Desa Tongke-Tongke dan dilantik pada tanggal 21 Maret 2003.

Sebagai bagian dari wilayah pemerintah Kecamatan Sinjai Timur, Desa Tongke-Tongke berbatasan langusug dengan wilayah pemerintah desa/kelurahan lainnya. Di sebelah Utara, berbatasan dengan Kelurahan Samataring. Di sebelah Timur, berbatasan dengan Teluk Bone. Di Sebelah Selatan, berbatasan dengan Desa Panaikang. Di sebelah Barat, berbatasan dengan Desa Kaloling. Selanjutnya, orabitasi jarak tempuh Desa Tongke-Tongke dengan-antara lain: dari Ibukota

\footnotetext{
${ }^{39}$ Lexy J. Moleong,Metodologi Penelitian Kualitatif,Cet. I; Bandung: Remaja Rosdakarya, 2005 , h. 330

${ }^{40}$ Disadur dari skripsi yang disusun oleh Rosnaeni. Lihat, Rosnaeni, Skripsi, Tinjauan Ekonomi Islam Terhadap Sistem Panjar Anak Buah Kapal (ABK) Nelayan (Studi Kasus di Desa Tongke-Tongke Kecamatan Sinjai Timur Sinjai) (Institut Agama Islam (IAI) Muhammadiyah Sinjai, 2017), h. 49-66. Dalam ingatan tetua di Desa Tongke-Tongke, bahwa dahulu kampung terkenal di wilayah ini adalah Maroanging. Di daerah Maroanging inilah sering diselenggarakan permainan rakyat yang disebut maggalenggo;menyepak buah kelapa sebagai adu ketangkasan pemuda. Karena itu, sebagai pengingat permainan tersebut berdiri Pondok Pesantren Darul Hikmah Lenggo-Lenggo. Nama "Lenggo-Lenggo" ini sendiri berasal dari istilah maggalenggo. Lihat, Hamzah Ya'qub, 20 Tahun Pesantren Darul Hikmah 1983-2003 (Profil Yayasan Pesantren Darul Hikmah Lenggo-Lenggo (jilid), tidak diterbitkan).
} 
Kecamatan $3 \mathrm{Km}$, dari Ibukota Kabupaten $5 \mathrm{Km}$, dan dari ibukota ProvinsiMakassar $220 \mathrm{Km}$.

Sejak menjadi wilayah pemerintahan, Desa Tongke-Tongke telah dipimpin oleh beberapa Kepala Desa, sebagai berikut:

1. Muhammad Nasri Daeng Lanna, periode 2003-2008

2. Adri Nur (Pjs) masa 2008-2010

3. H. Abdul Kadir periode 2010-2016

4. Sirajuddin periode 2016-sekarang

Letak wilayah Desa Tongke-Tongke yang berada di Bagian Timur Kabupaten Sinjai dan berbatasan langsung dengan laut Teluk Bone di sebelah Timur, dapat dikatakan sebagai daerah pesisir. Karena itu, sebagian besar penduduknya bermata pencaharian sebagai nelayan. Selain itu, ada pula yang berprofesi petambak, pengusaha, dan pegawai pemerintahan maupun swasta.

Desa Tongke-Tongke telah menasional ketika penghargaan bidang lingkungan yakni Kalpataru diberikan pada pemrakarsa hutan mangrove (bakau) H Taiyeb pada era Orde Baru dibawah kepemimpinan Presiden Soeharto pada 1995. Sejak saat itu, nama Desa Tongke-Tongke berikut hutan bakaunya mulai dikenal dan menjadi perbincangan di tingkat nasional sebagai contoh yang patut direplikasi oleh daerah pesisir lainnya di Indonesia. ${ }^{41}$ Kini, areal hutan mangrove menjadi destinasi wisata lokal, kawasan konservasi biota laut, dan tempat riset.

\subsection{Sejarah Eksistensi Tareqat Khalwatiyah Samman di Desa Tongke- Tongke Sinjai Timur}

Menentukan kapan Tareqat Khalwatiyah di Sinjai Desa Tongke-Tongke Sinjai Timur, belum didapatkan keterangan waktu yang jelas. Oleh karena itu, pembahasan mengenai eksistensi Tareqat Khalwatiyah di Sinjai Desa TongkeTongke Sinjai Timur, dibutuhkan telaah beberapa hasil riset dan referensi yang ada.

Martin Van Bruinessen menulis, bagi orang Bugis dan Makassar di Sulawesi Selatan, Tareqat Khalwatiyah memiliki pengikut yang banyak.

\footnotetext{
${ }^{41}$ https://www.mongabay.co.id/2019/07/10/meniti-tongke-tongke-jadi-magnet-sinjai/
} 
Meskipun dalam realitasnya Tareqat Khalwatiyah di daerah ini terbagi atas dua kelompok. Keduanya dikenal sebagai Tareqat Khalwatiyah Syekh Yusuf dan Tareqat Khalwatiyah Samman. Berdasarkan statistik dari kementerian Agama tahun 1973, tarekat Syekh Yusuf memiliki pengikut 25.000 orang, sedangkan Khalwatiyah Samman memiliki pengikut 117.435 orang. Khusus di Maros pada akhir abad XIX, Khalwatiyah Samman sangat berkembang pesat pada masa kepemimpinan H. Palopo-seorang guru kharismatik dengan jumlah pengikut 70.000 orang. Martin Van Bruinessen mengatakan, Khalwatiyah Samman lebih berkembang karena lebih banyak menyentuh masyarakat pedesaan. Sedangkan, Khalwatiyah Sykeh Yusuf bersifat "aristokrasi”, pengikut ajaran tarekat ini terbatas pada kaum bangsawan dan terpelajar saja. ${ }^{42}$

Di Sulawesi Selatan, dapat dikatakan bahwa pada abad XIX gerakan tarekat Khalwatiyah Samman banyak digandrungi. Hal ini disebabkan oleh ketokohan para khalifah, seperti H. Palopo dan tiga putra pelanjutnya. Tareqat Khalwatiyah Samman segera meraih simpati dan diikuti, karena bersifat inklusif. Tarekat ini terbuka untuk seluruh orang, tanpa memandang asal usul atau latar belakang seseorang. Berbeda dengan khalwatiyah Syekh Yusuf, tarekat ini terkesan ekskulsif. Pengajarannya dan penganutnya terbatas pada kalangan tertentu, atau terbatas pada kalangan bangsawan maupun orang terpelajar saja.

Tareqat Khalwatiyah adalah cabang dari Suhrawardiyah yang didirikan oleh Abdul Qadir al Suhrawardi sekitar tahun $1167 .{ }^{43}$ Di Sulawesi Selatan Tareqat Khalwatiyah terbagi dua, yakni Khalwatiyah Syek Yusuf berpusat di Cikoang Kab. Takalar dan Khalwatiyah Samman berpusat di Patte'ne Kab. Maros. ${ }^{44}$ Khalwatiyah Syekh Yusuf masuk ke Nusantara pada tahun 1672, dibawa oleh Syekh Yusuf Taj Al Khalwaty. Khalwatiyah Syek Yusuf dikembangkan oleh muridnya Abdul Basyir Puang Rappang di Sulawesi Selatan. Sedangkan Tareqat

\footnotetext{
${ }^{42}$ Martin Van Bruinessen, Kitab Kuning, Pesantren, dan Tarekat; Tradisi-Tradisi Islam di Indonesia (Cet. III; Bandung: Mizan, 1999), h. 285-286.

${ }^{43}$ A. Najamuddin Hamzah, Tarekat Khalwatiyah Samman; Ajaran dan Strategi Dakwah Para Khalifanya (Cet. I; Makassar: La Macca Press, 2007), h. 27.

${ }^{44}$ Tamsir T, Skripsi, Zikir (Maddate') dan Implementasinya (Tarekat Khalwatiyah Samman Dusun Cempa Desa Betao Riase Kecamatan Pitu Riawa Kabupaten Sidrap (UIN Alauddin Makassar, 2017), h. 22.
} 
Khalwatiyah Samman masuk ke Sulawesi Selatan sekitar tahun 1820 M/1240 H, dibawa oleh Syekh Abdullah al Munir. Pada masa kepemimpinan Khalifah H. Palopo, Tareqat Khalwatiyah Samman mencapai puncak popularitas dengan memiliki banyak pengikut. Setelah H. Palopo wafat, ia digantikan oleh ke tiga Putranya, yakni: Syekh H. Muhammad Shaleh Daeng Situru atau Puang Lompo, Syekh H. Muhammad Amin atau Puang Naba, dan Syekh H. Muhammad Ibrahim atau Puang Solong. ${ }^{45}$

Kedudukan tarekat Khalwatiyah Syekh Yusuf yang berpusat di Cikoang Takalar, dapat diprediksikan bahwa pengikut tareqat ini lebih banyak dari etnis Makassar. Sedangkan, pusat penyebaran tarekat Khalwatiyah Samman yang berkedudukan di Patteqne Maros, menunjukkan pengikut tarekat lebih banyak dari etnis Bugis. Pandangan ini didasarkan pula pada asal penganjur pertama masingmasing komunitas Khalwatiyah di Sulawesi Selatan.

Mustafa BS sebagaimana dikutip oleh A. Amrul Nurjaya mengatakan, Tareqat Khalwatiyah Samman dibawa oleh Syaikh Abdullah al Munir. Sepeninggal Syaikh Abdullah al Munir Tareqat Khalwatiyah Samman dilanjutkan oleh putranya Syaikh Muhammad Fudhail, seterusnya oleh Syaikh Abdul Razak. Penyebaran Tareqat Khalwatiyah Samman ini berpusat di Dusun Patte'ne Desa Temmapaduae Kec. Marusu Kab. Maros. ${ }^{46}$ Syaikh Abdul Razak juga dikenal dengan nama H. Palopo. ${ }^{47}$

Dapat dikatakan, masa kepemimpinan H. Palopo alias Syaikh Abd. Razak dan tiga putra pelanjutnya dikemudian hari, menjadikan tarekat Khalwatiyah Samman di Sulawesi Selatan mencapai puncak ketenaran. Di Maros saja, pengikut tarekat ini mencapai 70.000 orang. Statistik Kementerian Agama tahun 1972, penganut tarekat ini mencapai jumlah 117.435 orang yang tersebar diberbagai daerah di Sulawesi Selatan. Di bawah ini silsilah Tareqat Khalwatiyah Samman di Sulawesi Selatan,

1. Syekh Abdullah Munir

\footnotetext{
${ }^{45}$ A. Najamuddin Hamzah, Tarekat Khalwatiyah..., h. 20.

${ }^{46}$ A. Amrul Nurjaya, Skripsi, Pesan Dakwah Dalam Ajaran Tarekat Khalwatiyah Samman (Analisis Hermeneutika Paul Ricoeur (UIN Alauddin Makassar, 2017), h. 42.

${ }^{47}$ Grup Facebook, Tarekat Khalwatiyah Samman, diakses tanggal 15 Februari 2020.
} 
2. Syekh Muhammad Fudahil

3. Syekh Abd. Razak

4. Syekh Abdullah (Puang Lompo)/(Syekh H. Muhammad Shaleh Daeng Situru atau Puang Lompo $\left.{ }^{48}\right)$.

5. Syekh H. Ibrahim (Puang Solong), Syekh H. Andi Abdullah (Puang Rala)

6. Syekh Muhammad Amin (Puang Naba), Syekh Abd. Rauf (Puang Lallo), Syekh H. Andi Muhammad Ali (Puang Turu)

7. Syekh H. Muhammad Shaleh (Puang Lompo), Syekh H. Andi Amiruddin (Petta Karaeng), Syekh H. Andi Hamzah (Puang Nippi), Syekh H. Andi Sjadjaruddin Malik (Puang Tompo). ${ }^{49}$

Dari keseluruhan narasumber yang ditemui, pembahasan mengenai kapan masuk dan berkembangnya Tareqat Khalwatiyah di Desa Tongke-Tongke Sinjai Timur, dapat ditelusuri melalui ketokohan Puang Massiara. Puang Ambo NippiKhalifah sekarang, mengatakan "Khalwatiyah masuk di Maroanging (Sekarang Desa Tongke-Tongke) pada masa kolonial Belanda berkuasa di Sinjai”. ${ }^{50}$ Puang Massiara belajar Tareqat Khalwatiyah Samman kepada Muhammad Shaleh di Maros. ${ }^{51}$ Puang Massiara wafat sekitar tahun 1972, dalam usia 90 tahun. ${ }^{52}$

Merujuk keterangan narasumber tersebut, dapat dipastikan bahwa komunitas tareqat Khalwatiyah di Maroanging Baccara Desa Tongke-Tongke adalah penganut Tareqat Khalwatiyah Samman. Puang Massiara yang diyakini sebagai tokoh sentral tarekat Khalwatiyah di daerah ini, berguru kepada Syekh H. Muhammad Shaleh Daeng Situru atau Puang Lompo.

Peran Puang Massiara sebagai tokoh penting tarekat Khalwatiyah di Maroanging diakui oleh Hamzah Ya'qub-tokoh agama dan salah satu pendiri Pondok Pesantren Darul Hikmah Lenggo-Lenggo. Hamzah Ya'qub menulis, di Dusun Baccara kampung Maroanging berpusat gerakan Tareqat Khalwatiyah, di bawah pimpinan mursyidnya Puang Massiara. Murid-muridnya ramai berziarah dari pelbagai daerah di Sulawesi Selatan. Sepeninggal Puang Massiara, kepemimpinannya dalam tareqat ini dilanjutkan oleh Puang Muhammad (Sabiti.

${ }^{48}$ A. Najamuddin Hamzah, Tarekat Khalwatiyah..., h. 20.

49 Arfiandi, Skripsi, Kepatuhan Pengikut Ajaran Khalwatiyah Samman Terhadap Pemimpinnya Pada Pemilu Legisltaif 2014 (Universitas Hasanuddin, 2015), h. 77.

${ }^{50}$ Puang Ambo Nippi, Wawancara, pada tanggal 23 Desember 2019

${ }^{51}$ Puang Ambo Nippi, Ahmad Ghazali, Wawancara, pada tanggal 22-23 Desember 2019

${ }^{52}$ Qayyum, Wawancara, pada tanggal 24 Desember 2019 
Pen) yang bergelar Puang Lolo. Setelah wafatnya Puang Lolo, ia digantikan oleh putranya Ahmad (Ahmad Gazhali) yang saat itu menjadi Imam di Masjid Nurul Falah Maroanging. ${ }^{53}$

Catatan Hamzah Ya'qub ini memberi keterangan bahwa setelah Puang Massiara, khalifah Khalwatiyah selanjutnya adalah Muhammad Sabiti. Setelah itu, kepemimpinan diamanahkan kepada Ahmad Ghazali. Ketiga orang ini berada dalam satu garis keturunan, dari kakek, anak, dan cucu. Ahmad Ghazali tidak hanya menjabat sebagai khalifah Khalwatiyah di Baccara, tetapi diapun menjadi Imam Masjid Nurul Falah.

Puang Massiara wafat pada usia 90 sekitar tahun 1972, dengan demikian ia lahir sekitar tahun 1882. Merujuk pada beberapa kutipan sebelumnya, bahwa popularitas tareqat Khalwatiyah Samman meningkat ketika H. Palopo menjadi Khalifah pada akhir abad XIX. Hal ini berarti, Puang Massiara sudah menginjak usia remaja ketika H. Palopo/Syekh Abd. Razak menjadi khalifah. Setelah Syekh Abd. Razak/H. Palopo wafat, kepemimpinannya dilanjutkan oleh Syekh H. Muhammad Shaleh Daeng Situru atau Puang Lompo. Kepada Puang Lompo inilah Puang Massiara mattarima barakka; diterima sebagai pengikut tareqat Khalwatiyah Samman. Dengan demikian, dapat disimpulkan bahwa masuknya tareqat Khalwatiyah Samman di Maroanging/Desa Tongke-Tongke sekitar awal Abad XX (tahun 1900-an).

Namun demikian, Qayyum mengatakan, Khalifah pertama Tareqat Khalwatiyah di Maroanging adalah Muhammad Ghazali, kemudian seterusnya Puang Massiara, Muhammad Sabiti, Ahmad Ghazali, dan Ambo Nippi. Lebih lanjut Qayyum mengatakan: Muhammad Sabiti pernah menyampaikan bahwa dia sebenarnya sudah khalifah ke-5. ${ }^{54}$

Keterangan Qayyum memunculkan asumsi bahwa masih ada dua orang sebelum Muhammad Ghazali, tetapi tidak diketahui siapa nama mereka. Ketidakjelasan dua khalifah sebelum Muhammad Ghazali, hingga akhir riset ini dilakukan belum ditemukan keterangan tentang mereka. Meskipun didapatkan

53 Hamzah Ya'qub, 20 Tahun Pesantren Darul Hikmah 1983-2003 (Profil Yayasan Pesantren Darul Hikmah Lenggo-Lenggo (jilid), tidak diterbitkan)

${ }^{54}$ Qayyum, Wawancara, pada tanggal 24 Desember 2019 
informasi bahwa salah seorang khalifah memiliki catatan silsilah tareqat, akan tetapi "si pemilik" belum berkenan memperlihatkannya.

Untuk memperdalam analisis, berikut dikutip regenerasi yang valid khalifah tareqat Khalwatiyah Samman di Maroannging Desa Tongke-Tongke,

1. Muhammad Gazhali

2. Massiara (w. 1972)

3. Muhammad Sabiti/Puang Lolo

4. Ahmad Ghazali

5. Ambo Nippi (khalifah sekarang tahun 2020). ${ }^{55}$

Pernyataan Muhammad Sabiti/Puang Lolo bahwa sebenarnya ia adalah khalifah ke-5 sebagaimana diingat oleh Qayyum, melahirkan asumsi tareqat Khalwatiyah Samman telah masuk di Maroanging Desa Tongke-Tongke pada akhir abad XIX atau semasa dengan H. Palopo/Syekh Abd. Razak. Walaupun hanya asumsi karena belum didapatkan keterangan valid tentang dua orang khalifah sebelumnya, akan tetapi ajaran tareqat Khalwatiyah Samman sudah dikenal. Dalam kata lain, praktek ajaran tareqat Khalwatiyah Samman masih terbatas pada lingkup keluarga trah Puang Massiara atau belum disebarkan secara luas kepada anggota masyarakat lain di Maroanging. Penting diketahui bahwa suksesi khalifah dalam tareqat Khalwatiyah Samman berdasarkan keturunan atau memiliki hubungan darah yang sangat dekat dengan khalifah sebelumnya.

\subsection{Perkembangan dan Penyebaran Ajaran Tareqat Khalwatiyah Samman di Desa Tongke-Tongke Sinjai Timur}

Puang Massiara atau akrab disebut Puang Massi adalah khalifah tareqat Khalwatiyah Samman di Maroanging Desa Tongke-Tongke yang paling terkenal. Dia merupakan pemimpin tarekat Khlawatiyah Samman yang paling dihormati karena kharisma yang dimilikinya. Puang Ambo Nippi mengatakan, massemmeng bahang i Puang Massi na matau taue ${ }^{56}$ Berdehem saja, orang sudah segan dengan Puang Massi. Tampaknya, kharisma Puang Massi tidak terbatas di kalangan pengikutnya, tetapi pada masyakat di sekitarnya yang bukan pengikut.

\footnotetext{
55 Ambo Nippi dan Qayyum, Wawancara pada tanggal 23-24 Desember 2019 TongkeTongke

${ }^{56}$ Ambo Nippi, Wawancara pada tanggal 23 Desember 2019 Tongke-Tongke
} 
Puang Massiara memusatkan pengajaran tareqat Khalwatiyah Samman di Masjid Nurul Falah. Masjid ini berada di Dusun Baccara sekitar 5 km dari ibukota Kab. Sinjai. Sistem pengajaran yang dilaksanakan oleh Puang Massi adalah halaqah. Para murid/pengikut tarekat duduk melingkar sambil mendengar pengajaran. Tidak hanya sebagai tempat pengajaran ajaran tareqat Khalwatiyah, masjid Nurul Falah pun menjadi pusat pelaksanaan maddateq;zikir berjamaah setiap selesai shalat Subuh dan Isya. ${ }^{57}$

Hamzah Ya'qub menulis, di Dusun Baccara kampung Maroanging berpusat gerakan Tareqat Khalwatiyah, di bawah pimpinan mursyidnya Puang Massiara. Murid-muridnya ramai berziarah dari pelbagai daerah di Sulawesi Selatan. ${ }^{58}$ Banyak orang datang berguru kepada Puang Massi tareqat Khalwatiyah Samman, khususnya daerah sekitar Maroanging.

Boleh jadi, untuk pertama kali beberapa orang mengenal tareqat Khalwatiyah Samman melalui Puang Massi. Setelah belajar dan menjadi pengikut, mereka menyebar di berbagai daerah di Sulawesi Selatan. Untuk mengingat Puang Massi, mereka datang berziarah ke Makamnya di puncak bukit sebelah Barat Masjid Nurul Falah. Tidak hanya berziarah ke makam, akan tetapi sekaligus menjalin silaturrahim dengan anak cucu Puang Massi dan pengikut tareqat Khalwatiyah Samman di Maroanging Dusun Baccara.

Puang Ambo Nippi memberi keterangan, murid-murid Puang Massiara dari berbagai daerah antara lain: Bulukumpa-Kab. Bulukumba, Ujung-Bone, $\mathrm{H}$. Suyuti di Kec.Sinjai Tengah (Sattulu, Kompang, Bonto, Pattongko), Thamrin di Dusun Maccini Kec. Sinjai Timur, H. Arafah di Tana Ejae Lappae, Erasa, Petta Hasan di Balampangi. Tiga daerah terakhir berada di wilayah di Kec. Tellu Limpoe. Di Erasa (sekarang Desa Erabaru), Puang Massiara memiliki murid yang terkenal seperti: Solle, Laba, Lagassing, dan Bintang. Nama terakhir-Bintang, menjadi murid yang menonjol dikemudian hari sebagai pembina Tareqat Khalwatiyah Samman di Erasa. ${ }^{59}$

\footnotetext{
${ }^{57}$ Puang Sufu, Wawancara pada tanggal 25 Desember 2019 Tongke-Tongke

58 Hamzah Ya'qub, 20 Tahun Pesantren Darul Hikmah 1983-2003 (Profil Yayasan Pesantren Darul Hikmah Lenggo-Lenggo (jilid), tidak diterbitkan)

${ }^{59}$ Ambo Nippi, Wawancara pada tanggal 23 Desember 2019 Tongke-Tongke
} 
Sekitar tahun 1970 hingga 1990-an penganut Tareqat Khalwatiyah Samman dari Ujung Kab. Bone yang berdomisili di pasa toae;Pasar Tua Sinjai, rutin melakukan aktifitas zikir berjamaah di Masjid Nurul Falah. Hal itu berlangsung sejak kepemimpinan Muhammad Sabiti hingga Ahmad Ghazali. Memasuki awal tahun 2000-an aktifitas Zikir berjamaah (maddateq), mulai sepi hingga sekarang. Menurut Puang Ambo Nippi, hal ini disebabkan karena komunitas-komunitas penganut khalwatiyah Samman telah memiliki khalifah masing-masing. ${ }^{60}$

Penunjukan atau pengangkatan khalifah masing-masing komunitas Khalwatiyah Samman yang ada di Sinjai oleh Khalifah pusat di Maros, signifikan berdampak pada aktifitas tarekat ini di Desa Tongke-Tongke. Masjid Nurul Falah tidak lagi menjadi pusat konsentrasi penganut Khalwatiyah Samman. Akan tetapi, mereka tersebar di berbagai tempat. Dalam kata lain, silaturrahim dan konsolidasi antar penganut tarekat tidak intens. Boleh jadi pula, hal ini disebabkan oleh ketiadaan tokoh yang menjadi repsentasi tareqat Khalwatiyah Samman di Sinjai saat ini.

Ada hal menarik terkait dengan eksistensi penganut Khalwatiyah Samman di Desa Tongke-Tongke. Kehadiran sosok Muhammad Nur alias Puang Kure sebagai tokoh agama di Maroanging, dan juga memberikan pelajaran agama Islam di Masjid Nurul Falah. Meskipun aktifitas keagamaan antara Puang Kure dengan Puang Massiara, sama-sama berpusat di masjid Nurul Falah, tetapi tidak pernah terjadi konflik. Padahal Puang Kure bukan pengikut khalwatiyah Samman.

Sekaitan dengan realitas sosial tersebut, Hamzah Ya'qub mencatat,

Sezaman dengan Puang Massiara, tokoh lain- Muhammad Nur alias Puang Kure (w.1957) yang menjadi Imam di Masjid Nurul Falah Maroanging saat itu, turut andil dalam mengajarkan Islam. Puang Kure memusatkan pembelajarannya juga berpusat di Masjid Nurul Falah. Di Masjid ini, puang kure mengajarkan Hadis, Al Quran, dan Fiqih. Di Maroanging saat itu, di samping khalwatiyah terdapat pula organisasi Muhammadiyah dan ahlulsunnah lainnya. Keberadaan paham keagamaan yang berbeda ini, tidak menyebabkan terjadinya gesekan dalam masyarakat. Hal ini disebabkan karena adanya hubungan kekeluargaan yang terjaga dengan baik. Bila

${ }^{60}$ Dihimpun dari keterangan Ambo Nippi, Qayyum, dan Sufu, Wawancara pada tanggal 23-25 Desember 2019 Tongke-Tongke 
berkumpul, mereka hanya membicarakan Islam di masa depan, tidak mempertentang pemahaman keagamaan mereka yang berbeda. ${ }^{61}$

Merujuk pada keterangan tersebut, kerukunan dan toleransi kehidupan keagamaan di Baccara dan sekitarnya berlangsung dengan baik. Konflik sosial akibat perbedaan paham dan praktek keagamaan, tidak menjadi sebab interaksi sosial terganggu. Pada masa ini, tidak muncul istilah takfiri;saling mengkafirkan sesama muslim. Kesadaran terhadap perbedaan pendapat, pandangan, maupun praktek keagamaan dalam masalah furu'iyah bukan penghalang dalam kerjasama sosial. Dari sini pula tampak, pendekatan hubungan kekeluargaan cukup efektif dalam mencegah gesekan sosial keagamaan. Pembicaraan antara penganut Khalwatiyah dengan bukan pengikut, menyatu pada satu tema bahwa Islam itu harus didakwahkan. Dari sini, spirit fastabiqul khaerat; berlomba-lomba dalam berbuat baik menjadi praktis bukan sebatas teori/konsep.

Sejak awal tahun 2000-an, aktivitas penganut Khalwatiyah Samman di Desa Tongke-Tongke tidak seperti dulu lagi. Ritual maddateq sebagai ciri khas Khalwatiyah Samman di Masjid Nurul Falah tidak lagi dilaksanakan. Hanya ketika bulan maulud-Rabiul Awal ada kegiatan, itu pun masjid Nurul Falah menjadi tempat konsolidasi untuk koordinasi berangkat ke Patteqne Maros dalam rangka turut serta memperingati maulid Nabi Muhammad saw sekali setahun. Tampaknya, proses kaderisasi penganut tarekat penganut Khalwatiyah Samman di Desa Tongke-Tongke tidak berlansung dengan baik-khususnya di kalangan keluarga inti/anak cucu Puang Massiara.

\section{Kesimpulan}

Belum ditemukan keterangan valid mengenai kapan waktu pasti masuknya Tareqat Khalwatiyah khususnya Khalwatiyah Samman di Desa Tongke-Tongke. Akan tetapi berdasarkan telaah mendalam terhadap data-data yang terkumpul dan keterangan referensi yang ada, maka sejak akhir abad XIX ajaran Khalwatiyah Samman di Desa Tongke-Tongke telah dikenal. Dalam kata lain, praktek ajaran tarekat ini masih terbatas pada satu rumpun keluarga tertentu. Pada

61 Hamzah Ya'qub, 20 Tahun Pesantren Darul Hikmah 1983-2003 (Profil Yayasan Pesantren Darul Hikmah Lenggo-Lenggo (jilid), tidak diterbitkan) 
perkembangannya, didapatkan keterangan bahwa Puang Massiara atau Puang Massi merupakan tokoh yang kharismatik dan paling terkenal. Beliau belajar langsung ajaran Khalwatiyah Samman di Desa Tongke-Tongke kepada Syaikh Muhammad Shaleh-Khalifah Khalwatiyah Samman pusat di Patteqne. Dalam kajian mendalam riset ini, dapat ditetapkan bahwa tarekat Khalwatiyah Samman di Desa Tongke-Tongke mulai eksis dan menyebar sejak awal abad XX atau sekitar tahun 1900-an. Dengan demikian, jika dihitung dari sekarang tahun 2020, maka tareqat Khalwatiyah Samman di Desa Tongke-Tongke telah eksis dan bertahan sejak satu abad yang lalu. Berdasarkan data dan keterangan yang didapatkan, maka silsilah khalifah dapat dirunut sebagai berikut: 1. Muhammad Ghazali, 2. Massiara, 3. Muhammad Sabiti, 4. Ahmad Ghazali, 5. Puang Ambo Nippi.

Berdasarkan data-data yang didapatkan, penyebaran ajaran tareqat Khalwatiyah Samman tidak hanya di wilayah kab. Sinjai saja. Akan tetapi di wilayah kabupaten tetangga seperti Bulukumba dan Bone banyak yang menjadi penganut tareqat Khalwatiyah Samman. Khusus di wilayah Kab. Sinjai didapatkan keterangan tentang nama murid dan tempat ajaran tareqat Khalwatiyah Samman dianut. Seperti: H. Suyuti di Kec. Sinjai Tengah (Sattulu, Kompang, Bonto, Pattongko), Thamrin di Dusun Maccini Kec. Sinjai Timur, H. Arafah di Tana Ejae Lappae, Erasa-sekarang Desa Erabaru (Puang Massiara memiliki murid yang terkenal seperti: Solle, Laba, Lagassing, dan Bintang. Nama terakhirBintang, menjadi murid yang menonjol dikemudian hari sebagai pembina Tareqat Khalwatiyah Samman), Petta Hasan dan saudaranya di Balampangi. Tiga daerah terakhir berada di wilayah di Kec. Tellu Limpoe.

\section{DAFTAR PUSTAKA}

Al-Ghozaly, Syakirin. Ilmu Tasawuf Sebuah Pengantar, Cet. I; Sukoharjo: AISAswaja Institut Surakarta, 2010.

Anwar, Rosihan dan M. Solihin, Ilmu Tasawuf Cet.I; Bandung: CV. Pustaka Setia, 2008.

Arfiandy, Skripsi, Kepatuhan Pengikut Ajaran Khalwatiyah Samman Terhadap Pemimpinnya Pada Pemilu Tahun 2014, dikeluarkan oleh Universitas 
Hasanuddin Ilmu Makassar Fakultas Sosial dan Ilmu Politik Jurusan Ilmu Politik Pemerintahan Program Studi Ilmu Politik, 2015.

Atjeh, Aboebakar. Pengantar Ilmu Tareqat (Uraian Tentang Mistik), Cet.I; Solo: Ramadhani, 1985.

Bruinessen, Martin Van. Kitab Kuning, Pesantren, dan Tarekat; Tradisi-Tradisi Islam di Indonesia Cet. III; Bandung: Mizan, 1999.

Burhani, Ahmad Najib. Tareqat tanpa Tareqat,Cet.I; Jakarta: Serambi Ilmu Semesta, 2002.

Dhofier, Zamakhsyari. Tradisi Pesantren : Studi Pandangan Hidup yai dan Visinya Mengenai Masa Depan Indonesia, Cet. XI; Jakarta : LP3ES, 2011.

Elfrida, Skripsi, Pola Komuniksi Antar pribadi Dikalangan Jamaah Terekat Sammaniyah Menurut Pandangan Al-Quran Di Desa Teluk Sentosa Kecamatan Panai Hulu Kabupaten Labuhan Batu, dikeluarkan oleh Fakultas Dakwah Dan Komunikasi Universitas Islam Negeri Sumatra Utara Medan, 2017.

Grup Facebook, Tarekat Khalwatiyah Samman, diakses tanggal 15 Februari 2020.

Hajjaj, Muhammad Fauqi. Tasawuf Islam dan Akhlak, terj. Kamran As'at Irsyady dan Fakhri Ghazali, Cet. I; Jakarta: Amzah, 2011.

Hamid, Abu. Syeikh Yusuf Tajul Khalwat; Suatu Kajian Antropologi Agama, Cet. I; Ujung Pandang, Disertasi Ph.D Universitas Hasanuddin, 1990.

Hamzah, A. Najamuddin. Tarekat Khalwatiyah Samman; Ajaran dan Strategi Dakwah Para Khalifanya Cet. I; Makassar: La Macca Press, 2007.

https://www.mongabay.co.id/2019/07/10/meniti-tongke-tongke-jadi-magnetsinjai/

Madjid, Nurcholis. Islam Agama Peradaban, Cet. I; Jakarta: Paramadina, 1995, h.109.

Milles dan Huberman, Analisis Data Kualitatif, Cet. I; Jakarta: Universitas Indonesia Press, 1992.

Moleong, Lexy J. Metodologi Penelitian Kualitatif,Cet. I; Bandung: Remaja Rosdakarya, 2005.

Mulyati, Sri. Mengenal dan Memahami Tareqat-Tareqat Muktabarah di Indonesia, Cet IV; Jakarta: Prenada Media Group, 2011.

Mustafa, Ahmad. Akhlak Tasawuf, Cet. I; Bandung: CV. Pustaka Setia, 2010.

Nuh, Abd. Bin dan Oemar Bakry, Kamus Arab-Indonesia-Inggris, Cet. 15; Jakarta: Mutiara Sumber Widya, 2004.

Nurjaya, A. Amrul. Skripsi, Pesan Dakwah Dalam Ajaran Tarekat Khalwatiyah Samman (Analisis Hermeneutika Paul Ricoeur), dikeluarkan oleh UIN Alauddin Makassar Fakultas dakwah dan komunikasi Uin alauddin makassar, 2017. 
Nurjaya, A. Amrul. Skripsi, Pesan Dakwah Dalam Ajaran Tarekat Khalwatiyah Samman (Analisis Hermeneutika Paul Ricoeur, UIN Alauddin Makassar, 2017.

Rohmaniyah, Lu'lu'atul Izzatir. Skripsi, Strategi Adaptasi Tarekat Khalwatiyah Akmaliyah di Era Digital (Studi Kasus Di Desa Luwung Kecamatan Banyuputih Kabupaten Batang), dikeluarkan oleh UIN Sunan Kalijaga Yogyakarta Fakultas Ushuluddin dan Pemikiran Islam, 2018.

Rosnaeni, Skripsi, Tinjauan Ekonomi Islam Terhadap Sistem Panjar Anak Buah Kapal (ABK) Nelayan (Studi Kasus di Desa Tongke-Tongke Kecamatan Sinjai Timur Sinjai) (Institut Agama Islam (IAI) Muhammadiyah Sinjai, 2017.

Said, A. Fuad. Hakikat Tarikat Naqsyabandiyah, Hakikat Tarikat Naqsyabandiyah. Jakarta: Pustaka Al Husna Baru, 2005.

Shihab, Alwi. Akar Tasawuf di Indonesia, Cet. I; Depok; Pustaka IIMaN, 2009.

Sugiyono, Memahami Penelitian Kualitatif,Cet. I; Bandung: Alfabeta, 2009.

Sukmadinata, Metode Penelitian Pendidikan,Cet. I; Bandung:Rosdakarya,2007.

Sutopo, Metodologi Penelitian Kualitatif, Cet. I; Surakarta: Sebelas Maret University Press, 2002.

Syams, Badriyah. Tareqat sebagai Cara Pendekatan Diri Kepada Allah, Cet. I; Tangerang : CV. Sejahtera Kita, 2010.

Tamsir T, Skripsi, Zikir (Maddate') dan Implementasinya (Tarekat Khalwatiyah Samman Dusun Cempa Desa Betao Riase Kecamatan Pitu Riawa Kabupaten Sidrap, UIN Alauddin Makassar, 2017.

Tohir, Moenir Nahrowi. Menjelajahi Eksistensi Tasawuf; Meniti Jalan Menuju Tuhan, Cet.I; Jakarta: As Salam Sejahtera, 2012.

Wikipedia, 2018 https://id.wikipedia.org/wiki/Tarekat_Khalwatiyah, di akses tgl 21 Nopember 2019.

Ya'qub, Hamzah . 20 Tahun Pesantren Darul Hikmah 1983-2003 (Profil Yayasan Pesantren Darul Hikmah Lenggo-Lenggo (jilid), tidak diterbitkan).

Zahri, Mustafa . Kunci Memahami Ilmu Tasawuf, Cet. I; Surabaya: Bina Ilmu Offset, 1995.

\section{Wawancara Narasumber,}

Wawancara dengan narasumber dilakukan dari tanggal 22-25 Desember 2019 bertempat di Dusun Baccara-Maroanging dan di Dusun Babana Desa Tongke-Tongke.

Nara Sumber:

\section{No Data Keterangan}




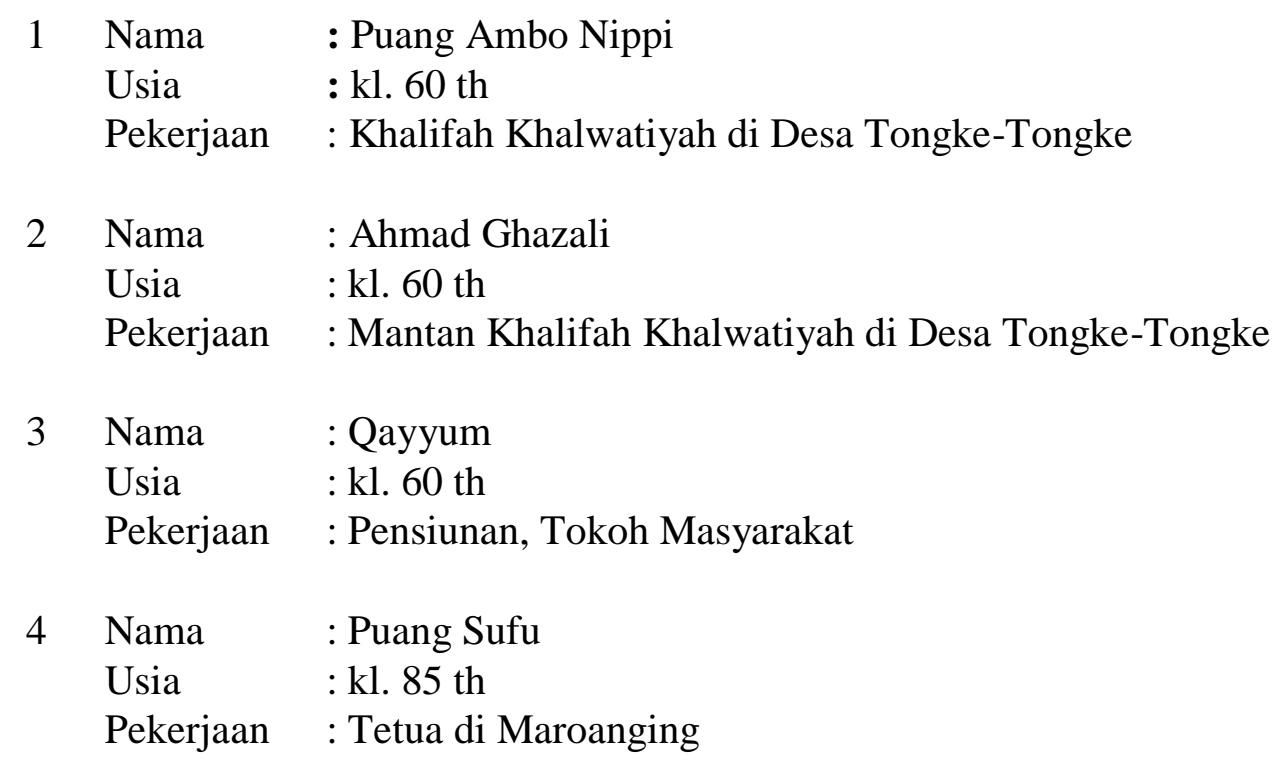

